\title{
Maxwell, Alexander. 2019. Everyday Nationalism in Hungary, 1789- 1867. Berlin/Boston: Walter de Gruyter. 258 pp.
}

\author{
Reviewed by Christopher M. Van Demark, ${ }^{*}$ New York University
}

Way back in 2015, as I struggled to piece together my undergraduate thesis on political fashions during the 1848 Hungarian Revolution, I was fortunate enough to happen upon Alexander Maxwell's Patriots Against Fashion: Clothing and Nationalism in Europe's Age of Revolutions (London, UK: Palgrave Macmillan, 2014). A sweeping comparative analysis of nationalist fashions stretching from the early-modern period to the early twentieth-century, Patriots helped me form the conceptual backbone of my own work, offering a theoretically sophisticated framework through which to examine the relationship between clothing and nationalism. Maxwell's new book, Everyday Nationalism in Hungary, 1789-1867, simultaneously enhances and narrows the scope of his previous work, exploring the nationalization of everyday objects and practices in nineteenth-century Hungary. Adopting a constructivist-empiricist approach to the study of nationalist development, Maxwell's book surveys the nationalization of everyday life thematically, through the lens of discrete customs, commodities, and consumer goods that patterned the day-to-day lifeworlds of ordinary Hungarians. Like Patriots, then, Everyday Nationalism is more preoccupied with the history of nationalism than with the history of fashion or with cultural history, interrogating the spread of national thinking at a crucial moment of patriotic agitation.

Everyday Nationalism is set primarily in the early decades of the nineteen-century, during the oft-cited era of Hungarian "national awakening." Eager to avoid any teleological pitfalls, however, Maxwell reconceptualizes and recasts the notion of "awakening," contending that it connotes a "... particular type of nationalism, specifically the early phases when poets like Sárváry, and patriots generally, began appending the adjective 'national' to everything imaginable" (11). By emphasizing the contingent, constructivist nature of nationalist ideologies, Maxwell formulates a theory of nationalism that leans heavily on the works of Rogers Brubaker, whose insights provide a framework for ".. thinking about the intersection between the national and other socio-historical variables" (242). Brubaker's reconceptualization of nationalism as a practical category allows Maxwell to develop a historical narrative that takes “... simultaneous and competing national agendas into account," distinguishing early nationalization in Hungary during the period of "national awakening" from studies of other sorts of nationalism (11).

*cmv352@nyu.edu

$($ (c) $)$ EY

ULLS D-Sunk
New articles in this journal are licensed under a Creative Commons Attribution 4.0 International License.

This journal is published by the University Library System of the University of Pittsburgh as part of its D-Scribe Digital Publishing Program and is cosponsored by the University of Pittsburgh Press 
Van Demark, Christopher M . "Maxwell, Alexander. 2019. Everyday Nationalism in Hungary, 1789-1867. Berlin/Boston: Walter de Gruyter. 258 pp. "Hungarian Cultural Studies. e-Journal of the American Hungarian Educators Association, Volume 13 (2020) DOI: 10.5195/ahea.2020.414

The first section of the book considers a common theme in Habsburg historiography, the contested nature of terminological conventions within pluri-national space. Maxwell argues that, in nineteenth-century Hungary, even the most basic language deployed by nationalist agitatorsterms such as "Hungarian," "nation" and endonyms such as "Magyar"-were objects of fierce debate (12). Charting the semantic evolution of these popular markers of national self-identity, Maxwell demonstrates how terminological conceptions of nationhood and national belonging reflected the political interests of their user. For instance, Slavic patriots affirmed their political rights within the plurilingual Kingdom of Hungary as "Hungarians," or "inhabitants of the Hungarian ('uhorsky') nation," rejecting the term "Mad'ar" ['Magyar'] as a signifier of the Hungarian-speaking population. In this way, Slavic polemicists positioned themselves in opposition to "... [Hungarian] pretensions to linguistic, cultural, and/or political supremacy within the multi-lingual Kingdom” (23). Hungarian-speaking proponents of Magyarization, on the other hand, consistently denied the legitimacy of the "Magyar"/ "Ungar" ['Hungarian'] distinction, using both terms interchangeably to designate belonging within the national collective.

Continuing his etymological analysis in the second chapter, Maxwell adopts an empiricist, inductive approach to explore the various interpretations of "nation" in nineteenthcentury Hungary. During the era of "national awakening," Magyar and non-Magyar patriots harbored vastly divergent conceptions of "nation," underscoring the highly contested and politicized nature of nationalist rhetoric. As Maxwell demonstrates, political disputes over the definition of "nation" were instrumental in defining, imagining, and shaping conceptions of ethno-national communities in the Kingdom of Hungary. Indeed, “... for Hungarian polemicists, both Magyar and non-Magyar, possessing the status of nation implied sovereignty and collective rights. Terminological disagreement had itself become a form of political contestation" (49). For Maxwell, then, the "nation" is a rhetorical construct, one that reflects opposing political stances deployed and propounded by historical actors. Rather than treating the "nation" as a discrete analytical category, Everyday Nationalism analyzes the processes through which certain nationalisms became embedded in everyday practice across overlapping ethno-national communities.

In the next section of the book, Maxwell turns to nationalized tobacco and alcohol respectively, developing a narrative that plumbs the economic dimensions of everyday nationalism in Hungary. Invoking the nation to defend their economic interests, Hungarian producers and exporters mobilized the masses to reject imperial claims to tobacco profits. Over time, however, tobacco patriotism began to transcend the narrow economic interests of industry elites, coming to signify friendship, honesty, and social solidarity, all of them traits that prominent Magyar patriots like István Széchenyi used to define civic virtue and "nationality" (82). As Maxwell notes, by the mid nineteenth-century, Hungarian tobacco "... took on a life of its own as a national symbol," surpassing economic, political, and ethnic ties in its broad cultural appeal (76). Similarly, in his chapter on national wine, Maxwell explicates how Hungarian patriots came to associate national wine with "... national excellence, cultural sophistication, economic growth, and progress generally" (109). Yet, unlike national tobacco, the major impediment to increased wine production and distribution was not high tariffs and overregulation by imperial authorities but transport costs and infrastructure challenges; thus, while both industries were contending with concrete economic challenges, Hungarian wine politics never reached the same pitch of anti-dynastic feeling when compared with national tobacco (100). It should be noted, however, that wine was only one of many alcoholic beverages consumed in 
Van Demark, Christopher M . "Maxwell, Alexander. 2019. Everyday Nationalism in Hungary, 1789-1867. Berlin/Boston: Walter de Gruyter. 258 pp. "Hungarian Cultural Studies. e-Journal of the American Hungarian Educators Association, Volume 13 (2020) DOI: 10.5195/ahea.2020.414

imperial Hungary. Other drinks, including beer and spirits, also developed national connotations, reflecting differences in status, background, and national allegiance. Expanding upon Michael Billig's notion of "banal nationalism," Maxwell articulates how Billig's admittedly narrow analytic framework may apply to everyday alcohol consumption in a pluri-ethnic space like nineteenth-century Hungary, simply by shifting the focus from the producers of national symbols and mass culture to their mainstream consumers.

In his chapters on patriotic facial hair and nationalized sexuality, Maxwell examines the gendered dimensions of national discourses during the era of "national awakening." While Hungarian moustache patriotism, like alcohol consumption, reflected the exclusionary ideologies of everyday nationalism in pluri-ethnic space, the politics of patriotic facial hair was also suffused with notions of "national manliness," lending debates over nationalized moustaches a distinctly gendered quality. Maxwell cites the findings of prominent feminist theorist, Carol Pateman, to articulate the inferior status of women within the movement for national liberation and in public life more generally. As Pateman notes, "[a]lmost no one - except some feminists is willing to admit that fraternity means what it says: the brotherhood of men" (The Sexual Contract; Stanford, CA: Stanford UP, 1988). Pateman's ideas about the systemic exclusion of women from nationalist movements are further confirmed in Maxwell's chapter on nationalized sexuality and the politics of marriage. Mapping the contours of nationalized [heterosexual] desire across multi-ethnic Hungary, Maxwell contends that the "... rhetoric of national endogamy sought to retain women as the collective possession of the national brotherhood" with nonnational marriages attracting the ire of some Hungarian patriots, Magyar and non-Magyar alike (170). However, as Maxwell demonstrates, sexual patriotism was rarely observed in the personal lives of Hungary's most prominent national agitators, with many of them eagerly entering into exogenous marriages. While Hungarian patriots treated sexual endogamy as the key to happiness and personal fulfillment for men, women's sexuality became a target of control, or what Cynthia Enloe has termed "political policing" of female sexual desire ("Feminism and Nationalism" in Athena Leoussi, ed., Encyclopedia of Nationalism; New Brunswick: Transaction, 2001). Like national facial hair, the rhetoric of nationalized sexuality was anchored in hegemonic ideas about national brotherhood and masculine belonging.

In his chapter on the development and evolution of Hungary's national costume, Maxwell assesses the patriotic significance of "... masculine uniforms and feminine fashions" throughout the nineteenth-century (186). When one speaks of a cohesive Hungarian "national costume," however, one must acknowledge the rich diversity of folk costumes found within the Kingdom of Hungary and the processes through which certain stylistic pedigrees gained traction over others in the national imagination. As Maxwell rightly points out, in the early nineteenth-century, peasant costumes “... varied not from nation to nation (or 'nationality' to 'nationality'), but from village to village, or even within a village" (188). Thus, the díszmagyar ['Hungarian gala'] costume, which became the most popular Hungarian men's costume by the middle of the nineteenth-century, was the product of a long process of standardization and omission, as Hungarian patriots invested the characteristic dolmány, an intricately braided short coat, and mente, a fur lined overcoat, with concrete national significance. During the Reform Era, the díszmagyar ensemble became a potent symbol of national pride and imperial opposition, retaining its nationalist associations even after the 1848 Revolution and into the oppressive Bach Era, only losing its political edge by the latter portion of the nineteenth-century amidst dynastic reconciliation. Likewise, nationally-engaged women developed patriotic ensembles that incorporated some of the signature stylistic elements of the masculine diszmagyar costume, 
Van Demark, Christopher M . "Maxwell, Alexander. 2019. Everyday Nationalism in Hungary, 1789-1867. Berlin/Boston: Walter de Gruyter. 258 pp. "Hungarian Cultural Studies. e-Journal of the American Hungarian Educators Association, Volume 13 (2020) DOI: 10.5195/ahea.2020.414

rearticulating the hegemonic nature of masculine authority over nationalized clothing. There were some instances, however, when feminine magyaros ['Hungarian style'] costumes drew inspiration from other sources, most notably the tricolor flag. Maxwell concludes this chapter by connecting the politically contingent trajectory of Hungarian national dress to Tara Zahra's concept of "national indifference," an analytic approach to the study of nationalism that could be applied fruitfully to many topics discussed in Everyday Nationalism.

Theoretically rigorous and analytically nuanced, Maxwell's newest release is a welcomed addition to the bookshelf of any student of Hungarian history. Attentive to recent advancements in the discipline and their applicability to pluri-national Habsburg Europe, Everyday Nationalism links early nationalization practices in nineteenth-century Hungary to foundational works on nationalist theory, engaging with preeminent texts by Anthony Smith, Eric Hobsbawm, Benedict Anderson, and others. At its core, Everyday Nationalism examines norms and everyday practices during a moment of "effervescent nationalism" in the Kingdom of Hungary, a period marked by widespread nationalist agitation and organization. The study of everyday nationalism in Hungary, its scope, its efficacy, and its limits, represents a subfield that would certainly benefit from more attention from historians of East/Central Europe, and Everyday Nationalism in Hungary, 1789-1867 should be considered a significant contribution to this bourgeoning research field. 